\title{
Locally Advanced Bladder Urothelial
} Carcinoma

National Cancer Institute

\section{Source}

National Cancer Institute. Locally Advanced Bladder Urothelial Carcinoma. NCI

Thesaurus. Code C162618.

A bladder urothelial carcinoma that has spread from its original site of growth to nearby tissues or lymph nodes. 